Niniejsza publikacja jest dostęna na licencji Creative Commons. Uznanie autorstwa-Użycie niekomercyjne-Bez utworów zależnych 3.0 Polska. Pewne prawa zastrzeżone na rzecz autora. Zezwala się na wykorzystanie publikacji zgodnie z licencja - pod warunkiem zachowania niniejszej informacji licencyjnej oraz wskazania autora jako właściciela praw do tekstu. Treść licencji jest dostępna na stronie: http://creativecommons.org/licenses/by-nc-nd/3.0/pl/

Lingwistyka Stosowana 23: 3/2017, 1-14

\author{
Anna P. BOROWSKA \\ Uniwersytet Warszawski
}

\title{
Dyferencjacja zadań badawczych awialingwistyki na tle bieżących potrzeb lotnictwa
}

\begin{abstract}
:
Various research tasks of avialinguistics against current aviation needs

The author presents various research tasks of a new scientific discipline - avialinguistics, called and described by herself earlier (see A.P. Borowska 2017a). This new branch of linguistics deals with various types of aviation texts. Aviation discourse is a specific variety of specialist discourse as common features with other specialist varieties are found to be marginal. The needs of civil aviation increase proportionally to research needs and improving its aspects including aviation communication. The article presents the subject and aims of avialinguistics in order to present its various research tasks with reference to current aviation needs and taking into account the variety of aviation polilects. Aeronautical discourse has been selected as an example for scientific discussion.
\end{abstract}

\section{Wstęp}

Bezpieczeństwo każdego lotu nie ogranicza się tylko do aspektów technicznych związanych z nowoczesnymi technologiami lub jakością stosowanych materiałów. Obejmuje ono także, a może przede wszystkim, czynnik ludzki, który ciągle ma olbrzymie znaczenie podczas każdej operacji lotniczej. Do tej pory zjawisko to było analizowane na gruncie różnych dyscyplin, np. lotnictwa (J.A. Caldwell/ J.Y. Caldwell 2016; T.G.C. Griffin/ M.S. Young/ N.A. Stanton 2015; V.D. Hopkin 1995; H.C. Muir/ D. Harris 2005; J.A. Wise/ V.D. Hopkin/ D.J. Garland 2009), psychologii w lotnictwie (M. Martinussen/ D.R. Hunter 2010; P.S. Tsang/ M.A. Vidulich 2002), czy lingwistyki w kontekście lotniczym (S. Cookson 2009; B. Molesworth/ D. Estival 2015). Często jednak badania wskazywały bardzo uogólnione wyniki i były ze sobą niespójne. Wraz z coraz większą potrzebą klarownej i globalnie zrozumiałej lotniczej komunikacji werbalnej pojawiła się konieczność stworzenia oddzielnej dyscypliny wiedzy, która wykorzystując potencjał dziedzin jej pierwotnych mogłaby interpretować na nowo dotychczasowe ustalenia na tle bieżących potrzeb lotnictwa i objąć specyficzne cele służące usprawnieniu wszystkich aspektów werbalnej komunikacji lotniczej. Dziedzina ta została po raz pierwszy nazwana i opisana w języku angielskim przez A.P. Borowską (2017a) jako avialinguistics, a jej założenia poparte przeprowadzonymi badaniami (zob. A.P. Borowska 2017a). Zasto- 
sowana oryginalnie przez autorkę angielska nazwa pozwoliła sprawnie dokonać transferu terminu na grunt języka polskiego, w wyniku czego powstała nazwa polska - awialingwistyka.

Bieżące potrzeby wynikające $\mathrm{z}$ intensywnego rozwoju transportu lotniczego na świecie i zapewnienia bezpieczeństwa operacji lotniczych obejmują między innymi komunikację specjalistyczną w języku angielskim, a zatem mają na uwadze nieustanne podnoszenie kompetencji językowych kadr przemysłu lotniczego. Niezbędne zadania badawcze w tym zakresie charakteryzują się coraz głębszą dyferencjacją zależnie od specyficznych celów poszczególnych dziedzin lotnictwa, a więc także poprawnej komunikacji werbalnej stosowanej do ich osiągnięcia. Zadaniem awialingwistyki jest zatem zaspokojenie wszelkich potrzeb językowych służących osiągnięciu poprawnej komunikacji.

\section{Przedmiot awialingwistyki}

Awialingwistyka to nowa interdyscyplinarna dziedzina wiedzy zajmująca się badaniem języka lotniczego we wszystkich jego aspektach i w ścisłym powiązaniu z praktycznym jego stosowaniem. Jej nazwa wywodzi się z dwóch dziedzin względem niej prymarnych, tj. awiacji (synonim lotnictwa - ang. aviation) i lingwistyki (ang. linguistics), bez których nie mogłaby istnieć ${ }^{1}$. Ta nowa dziedzina wiedzy jest pochodną lingwistyki stosowanej, a także lingwistyki specjalistycznej. Dzieli zatem z nimi wspólny aparat badawczy. Awialingwistyka jest także pochodną lingwistyki ogólnej, ponieważ analizuje tworzenie i rozumienie wypowiedzi ustnych i pisemnych. Dzięki awialingwistyce, po raz pierwszy język lotniczy może stanowić główny przedmiot badania teoretycznego i empirycznego. Stosowanie języka lotniczego kieruje badacza w stronę użytkownika tego języka oraz tekstów, które on w nim wytworzy. Po pierwsze, takimi użytkownikami są przede wszystkim specjaliści różnych dziedzin lotnictwa tworzący i rozumiejący teksty w danym języku lotniczym, np. w polskim języku lotniczym, niemieckim języku lotniczym itd. Po drugie, teksty te służą osiągnięciu założonych celów komunikacyjnych, czyli stanowią swoiste narzędzie zawodowe. Stąd też potrzeba dyscypliny, która mogłaby scalić cele językowe z lotniczymi. Powstała dziedzina wiedzy otwiera nowe perspektywy badawcze, a także wzajemne rozpoznanie potrzeb, co prowadzi do współpracy językoznawców badających język lotniczy ze specjalistami posługującymi się nim do celów zawodowych. Celem wspólnym może być usprawnienie samego języka lotniczego, a w konsekwencji komunikacji lotniczej. Graficznie awialingwistyka może być zatem przedstawiona jako częśc wspólna lingwistyki i lotnictwa:

\footnotetext{
${ }^{1}$ Więcej na temat procesu tworzenia nazwy avialinguistics zob. A.P. Borowska (2017a).
} 


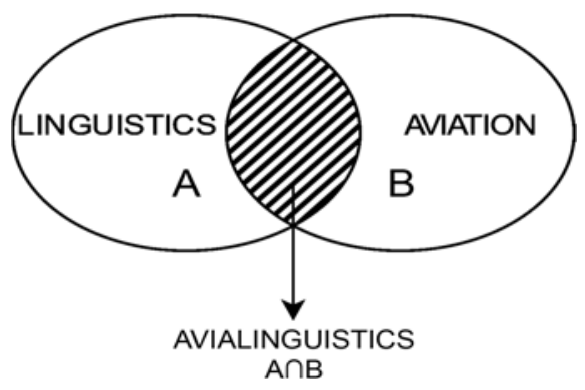

Rys. 1 Rejon badawczy awialingwistyki (A.P. Borowska 2017a).

Chociaż język angielski został ustanowiony językiem lotnictwa w 1951 przez Organizację Międzynarodowego Lotnictwa Cywilnego (ang. International Civil Aviation Organization - ICAO), potrzeba obserwacji naukowej i analizy języka lotniczego pojawiła się stopniowo wraz z rozwojem lotnictwa i służącej mu komunikacji werbalnej, a nasiliła się po tragicznych w skutkach wypadkach lotniczych, w których niepoprawne zastosowanie języka lub jego niepoprawna interpretacja stanowiły główne lub pośrednie przyczyny katastrof, np. Zagrzeb 1976; Teneryfa 1977; Cove Neck, Nowy Jork (Avianca) 1990; Kolumbia 1995; Indie 1996.

Należy podkreślić, że awialingwistyka nie ma na celu zbadania jednego języka lotniczego, ani jego teoretycznego modelu, bo taki język nie istnieje, a model może stanowić jedynie wzór pomagający przyswoić gramatykę i leksykę danego języka lotniczego: „W rzeczywistości nie istnieje żaden jednorodny, ani żaden jeden język specjalistyczny - również na płaszczyźnie idiolektów" (S. Grucza 2004: 154). Przedmiotem badań są zatem konkretne języki oraz teksty stworzone w tych językach przez specjalistów z branży lotniczej. Ponadto awialingwistyka nie musi badać jednocześnie wszystkich rodzajów tekstów lotniczych, lecz może ograniczyć swoje badanie do jednego rodzaju takich tekstów. Mogą to być zarówno teksty pisane, jak i mówione dotyczące każdej dziedziny lotnictwa. J. Karpiński (2015: 24) zauważa, że bez wątpienia komunikacja między specjalistami jest jednym z podstawowych aspektów języka awiacji. Nie można jednak zapomnieć o innych osobach zaangażowanych w każdy lot i wykorzystujących nie tylko terminologię lotniczą w swoich wypowiedziach, ale także inne elementy językowe i pozajęzykowe charakterystyczne dla tej komunikacji.

Awialingwistyka może być różnicowana ze względu nie tylko na swój cel, ale przede wszystkim przedmiot. Jak wspomniano powyżej, przedmiotem badań awialingwistyki jest język lotniczy we wszystkich swoich odmianach narodowych oraz we wszystkich aspektach zawodowych związanych z lotnictwem, a także poszczególne (pod)języki i narzędzia służące komunikacji werbalnej (ang. tools) stanowiące jego podzbiory. Nie jest to zatem tylko i wyłącznie globalny Aviation English. Ponadto techniczna komunikacja lotnicza oraz komunikacja aeronautyczna wykorzystują do realizacji swoich celów właśnie specyficzne kody językowe, których nie można nazwać pełnymi językami ze względu na ich ograniczone funkcje, a także 
sposób tworzenia wypowiedzeń i ściśle określony leksykon (zob. A.P. Borowska 2017a). Sam przedmiot awialingwistyki jest generowany przez różnego rodzaju obiekty brane pod uwagę podczas badania, ich właściwości, a także zbiór relacji pomiędzy tymi obiektami i właściwościami (zob. L. Nowak 1977; F. Grucza 2003, 2007; S. Grucza 2008). Specjaliści tworząc wypowiedzenia posługują się własnym idiolektem lotniczym, a poszczególne idiolekty składają się na ogólnie rozumiany polilekt lotniczy. Takie idiolekty mogą być traktowane jako obiekty, a właściwości odnoszą się do właściwości tekstu lub wypowiedzenia skonstruowanego $\mathrm{w}$ danym idiolekcie.

Biorąc powyższe rozważania pod uwagę, możemy zdefiniować przedmiot awialingwistyki, czyli język lotniczy jako język specjalistyczny stosowany do celów komunikacji lotniczej, realizowany za pomocą różnych (pod)języków i narzędzi językowych, które składają się na jego specyficzne podzbiory, a które mogą wykorzystywać w pewnym stopniu wspólny leksykon lotniczy i struktury gramatyczne danego języka naturalnego. Jednak każdy z takich podzbiorów charakteryzuje się cechami indywidualnymi. Wiedza dotycząca języka lotniczego (JL) może być usystematyzowana za pomocą teorii zbiorów. Szczegółowo można zatem mówić między innymi o podzbiorze czy (pod)języku prawa lotniczego, (pod)języku aeronautycznym, (pod)języku personelu pokładowego, (pod)języku medycyny lotniczej, uproszczonym lotniczym (pod)języku technicznym (Simplified Aviation English), (pod)języku obsługi pasażerów, (pod)języku obsługi naziemnej itd. Powyższe rozważania przedstawia następujący wzór, gdzie $J L$ stanowi zbiór, a jego elementy to wymienione powyżej przykłady przedstawione za pomocą symboli $x_{1}, x_{2}, x_{3}, \ldots, x_{n}$ :

$$
\mathrm{JL}=\left\{\mathrm{x}_{1}, \mathrm{x}_{2}, \mathrm{x}_{3}, \ldots, \mathrm{x}_{\mathrm{n}}\right\}
$$

Według takiego podziału język lotniczy nie może stanowić żadnego konkretnego języka, a tylko nadrzędny konstrukt badawczy, będący punktem wyjścia do badań szczegółowych. Tylko od badacza zależy, który podzbiór (lub podzbiory) zamierza poddać analizie.

Na uwagę zasługuje również fakt, że cechą charakterystyczną, a zarazem oryginalną, niektórych podzbiorów języka lotniczego jest jego kodowość. Takie podzbiory nazywane są zazwyczaj narzędziami językowymi, ponieważ zostały stworzone sztucznie w celu spełnienia określonej funkcji komunikacyjnej. Zaliczamy do nich Simplified Aviation English, a także standardową frazeologię, która razem z 'plain English’ składa się na angielski język aeronautyczny² (ang. Aeronautical English), który służy komunikacji pomiędzy pilotem a kontrolerem ruchu lotniczego, pilotem a pilotem, a także w razie potrzeby między pilotem a obsługą naziemną. Przymiotnik aeronautyczny przyjął się już na gruncie polskim w celu określenia np. przyrządów i innych przedmiotów wykorzystywanych w żegludze powietrznej. Możemy zatem $\mathrm{z}$ powodzeniem stosować go do nazwania specyficznej odmiany językowej w

2 Więcej na temat opisu lingwistycznego angielskiego języka aeronautycznego zob. A.P. Borowska (2017a). 
celu odróżnienia jej od pojęcia bardziej ogólnego, jakim jest język lotniczy. Przedmiotem badania awialingwistycznego może być zatem również narzędzie językowe, niebędące standardowym językiem lub podjęzykiem, ale służące do komunikacji werbalnej między specjalistami.

\section{Dyskurs lotniczy a jego odmiany}

Język używany jest do tworzenia tekstów. Zasady tworzenia wypowiedzeń lotniczych różnicują się proporcjonalnie do celu komunikacyjnego, czyli funkcji, jakie dany rodzaj dyskursu powinien spełniać. B.L. Gunnarson (2009) podkreśla, że dyskurs zawodowy odgrywa kluczową rolę $\mathrm{w}$ obecnym społeczeństwie, ponieważ umożliwia tworzenie i utrzymanie organizacji o podobnych celach, co często wychodzi poza standardowe stosowanie języka. Na nazwanie dyskursu stosowanego w lotnictwie tradycyjnie stosuje się termin dyskurs lotniczy i tylko kontekst pozwala określić, jakiego konkretnego typu jest to dyskurs. Praktyka taka może być jednak myląca dla jego badaczy, a także dla badaczy dyskursu innych dziedzin. Należy zatem sprecyzować, czym konkretnie jest dyskurs lotniczy i jak poprawnie nazywać jego odmiany. Dyskurs lotniczy jako termin nadrzędny obejmuje każdy typ dyskursu stosowanego w lotnictwie. Możemy mówić o dyskursie personelu pokładowego, dyskursie obsługi naziemnej, dyskursie mechaników lotniczych, czy dyskursie aeronautycznym. Stosując proponowane terminy, od razu zawężamy pole analizy, a nasz przekaz staje się bardziej klarowny.

Każda odmiana dyskursu lotniczego może dodatkowo charakteryzować się wewnętrznymi regułami i ściśle określać, jakich struktur gramatycznych należy użyć podczas konstruowania wypowiedzi. Przykładem jest zróżnicowany w swoim rodzaju angielski dyskurs aeronautyczny, który wymaga stosowania standardowej frazeologii lotniczej podczas operacji rutynowych i tzw. ogólnego angielskiego języka lotniczego (A.P. Borowska 2012), nazwanego oryginalnie plain English (ICAO) podczas operacji nagłych i niestandardowych. Nazwa ta wzbudza wciąż wiele kontrowersji ze względu na fakt, że przymiotnik plain odnosi się do języka ogólnego, a plain English nie jest takim językiem, chociaż wykorzystuje jego elementy. Dlatego zaproponowano inne nazwy, tj. Plain Aviation English (M. Bieswanger 2016) i Plain Aeronautical English ${ }^{3}$ (A.P. Borowska 2017a). Dodatkowo coraz popularniejsze i szeroko stosowane są także krótkie wiadomości tekstowe CPDLC ${ }^{4}$ (ControllerPilot Data Link Communications), które służą jako uzupełnienie pełnego przekazu ustnego. Zatem jeden typ dyskursu może obejmować jego różne rodzaje ze względu na rodzaj funkcji, jaką ma on pełnić. Poniższe przykłady (1), (2) i (3) ilustrują zróżnicowanie rodzajów dyskursu aeronautycznego na każdym z podstawowych pozio-

\footnotetext{
${ }^{3}$ Zwany też po polsku językiem potocznym w thumaczeniu dokumentu ICAO 9835. Jednak nazwa ta może być myląca (A.B.).

4 ,2.2.5.1.1 CPDLC is a data link application that supports the exchange of data messages directly between a controller and a flight crew" (ICAO: Global Operational Data Link Document (GOLD), Second Edition, 26 April 2013).
} 
mów analizy tekstu specjalistycznego, tj. typ tekstu (ustny lub pisemny) i jego budowa, stosowane struktury gramatyczne, a także stosowany leksykon:

Przykład (1) frazeologia standardowa

Kontroler: United 1448, thank you, taxi to ramp, via taxiways $\mathrm{N}$ and $\mathrm{T}$, report crossing runway 16 .

Pilot: OK, N, T, will report crossing Runway 16, United 1448.

(www.liveATC.net, JFK)

Przykład (2) ogólny angielski język lotniczy

Pilot: Etihad 102, we experience medical emergency onboard. Three-year-old boy Emirate, having lung problems continue on oxygen. We need to divert to Stockholm-Arlanda.

Kontroler: Etihad 102, Roger. Turn left heading 010, you will land runway 19R.

Pilot: Left heading 010, confirm?

Kontroler: Left heading 010, correct.

(www.liveATC.net, JFK)

Przykład (3) wiadomość tekstowa CPDLC

Kontroler: REPORT MAINTAINING FL370

Pilot: MAINTAINING FL370.

(GOLD 2013)

Budowanie wypowiedzi w dyskursie aeronautycznym nie polega tylko na doborze odpowiednich terminów i poprawnych struktur językowych. Wszystkie powyższe dialogi są zbudowane zgodnie z przyjętymi zasadami prowadzenia dyskursu aeronautycznego, które Eurocontrol (2006) przedstawiła za pomocą poniższego modelu:

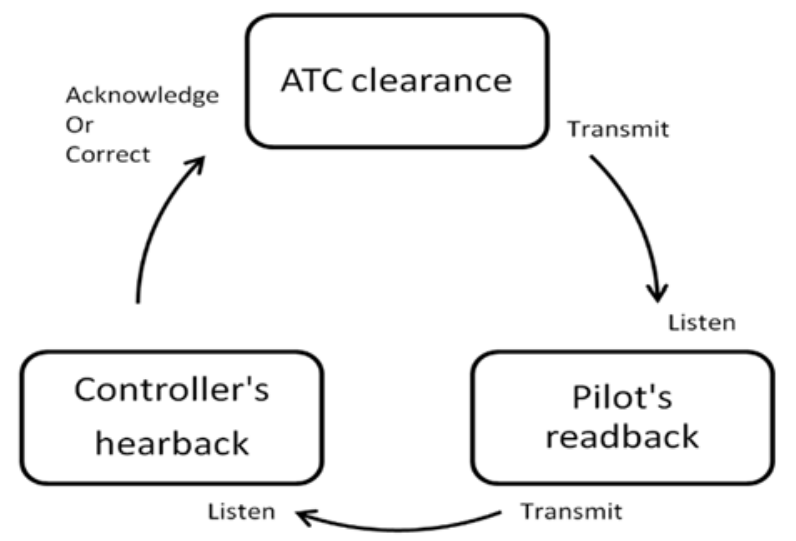

Rys. 2 „Pętla” komunikacyjna pilot-kontroler (Eurocontrol 2006).

Model zawodowej komunikacji pomiędzy pilotem a kontrolerem ruchu powietrznego lub naziemnego został tu przedstawiony na przykładzie ,pętli” (ang. loop). Po- 
szczególne elementy takiej pętli, czyli wypowiedzi pilota lub kontrolera, wymagają natychmiastowej reakcji interlokutora. Nie można również pominąć żadnego z przedstawionych elementów podczas dialogu, ponieważ może to wpłynąć na bezpieczeństwo lotu. Dlatego po pozwoleniu na daną operację wydanym przez kontrolera (ATC clearance) musi nastapić powtórzenie instrukcji przez pilota (pilot's readback), którego uważnie słucha kontroler celem ewentualnej poprawy błędnej interpretacji takiej instrukcji (controller's hearback). Dopiero po całej procedurze pilot może rozpocząć wykonywanie danej operacji statku powietrznego.

Cechy charakterystyczne dla wybranego rodzaju dyskursu lotniczego zawsze muszą być uwzględnione przy nakreślaniu zadań badawczych, co pozwoli na określenie problemu, dogłębna analizę i trafne wyciągnięcie wniosków z przeprowadzonego badania.

\section{Dyferencjacja zadań badawczych awialingwistyki}

Awialingwistyka może być różnicowana ze względu na zadania badawcze, jakie ma spełnić. Są one ściśle związane z bieżącymi potrzebami lotnictwa ze względu na fakt, że awialingwstyka jako dziedzina interdyscyplinarna ma takie potrzeby przede wszystkim i priorytetowo uwzględniać. Stanowią też one często punkt zwrotny w prowadzonych badaniach. Aby dany język lotniczy został poddany bezpośredniej obserwacji, należy znać nie tylko kontekst jego użycia i stosowaną terminologię czy gramatykę, ale cel konstruowanego w nim tekstu. Lista cząstkowych zadań badawczych jest bardzo zróżnicowana. Awialingwistyka stawia sobie zarówno cele komparatywne, jak i aplikatywne. Cele komparatywne mogą dotyczyć między innymi porównania zbiorów tekstów i/lub języków lotniczych funkcjonujących w obrębie dwóch lub więcej wspólnot językowych (za S. Gruczą 2004: 156). Badania aplikatywne awialingwistyki mają na celu ulepszenie obecnego stanu (pod)języków lotniczych, a zatem redukcję popełnianych błędów, poprawne stosowanie terminologii i/lub dobór startegii komunikacyjnych.

W celu przedstawienia zadania badawczego awialingwistyki należy przede wszystkim na samym początku określić:

- przedmiot badania, a zatem który podzbiór języka lotniczego podlega analizie i czy badany konstrukt jest idiolektem czy polilektem lotniczym;

- typ tekstu - czy badanie dotyczy tekstu pisemnego czy ustnego i jakie są jego funkcje;

- cel badania - czy cel badania wpisuje się w bieżące potrzeby lotnictwa;

- metodę badawczą.

Do ogólnych zadań badawczych awialingwistyki zalicza się obserwację, analizę i opis wybranego (pod)języka lub narzędzia językowego w użyciu, dla których konstrukt język lotniczy stanowi termin nadrzędny. Pod uwagę nie jest zatem brany tylko specjalistyczny leksykon jako system znaków, ale wszystko, co składa się na werbalną komunikację lotniczą, np. dobór struktur gramatycznych przez użytkowników, intonacja, strategie stosowane podczas komunikacji oraz zachowanie werbalne i schematy zachowań kulturowych. Taka obserwacja i analiza dostarcza wiedzy na 
temat obecnego stanu języka lotniczego i automatycznie dąży do szukania rozwiązań celem jego usprawnienia.

A.P. Borowska (2017a) dokonuje podziału awialingwistyki na awialingwistyke czysta i awialingwistyke stosowana, co wspomaga precyzyjne nakreślenie zadań badawczych. Pomimo że obydwa rodzaje awialingwistyki dotyczą tego samego przedmiotu naukowego w tym samym kontekście badawczym, dążą do znalezienia rozwiązań innych problemów naukowych. Awialingwistyka czysta zajmuje się celami podstawowymi:

The aims of pure avialinguistics are $\mathrm{AL}^{5}$ analysis and description, the ability to use $\mathrm{AL}$ as an ability to create logical special-purpose utterances and texts as well as the ability to interpret them, so logically the nature of aviation communication and its mechanisms. Moreover, pure avialinguistics covers aviation language teaching and translation studies with all possible subfields, e.g. teaching the translation of aviation texts (A.P. Borowska 2017a).

Awialingwistyka stosowana pośredniczy między teorią a praktyką. Jej zadaniem jest przede wszystkim zebranie i dostarczenie niezbędnych danych celem usprawnienia procesu szkolenia, testowania, oceniania kompetencji językowych, a także pozostałych obszarów, w których wykorzystywany jest język lotniczy, tj. szkolenia trenerów języka lotniczego, tłumaczenie tekstów lotniczych, nauczanie takiego thumaczenia czy prace terminologiczne. Proces taki wiąże się z nieustanną współpracą specjalistów językoznawców ze specjalistami branży lotniczej. Niezbędna wymiana doświadczeń i wiedzy fachowej obu dyscyplin - językoznawstwa i lotnictwa umożliwia zatem pełne osiągnięcie założonych celów.

Jak wspomniano powyżej, awialingwistyka czerpie także wiedzę i metody empiryczne z lingwistyki języków specjalistycznych. Zgodnie z jej założeniami, zadania awialingwistyki można zatem podzielić na diagnostyczne, anagnostyczne i prognostyczne (zob. S. Grucza 2013: 137). Chociaż mają one na celu pozyskanie innego rodzaju wiedzy, jest to wiedza o tym samym przedmiocie. S. Grucza (2013) podkreśla, że człon zadań, od którego lingwistyka języków specjalistycznych - jak każda inna dziedzina nauki empirycznej - musi rozpocząć swoje rozważania i badania, to człon nazwany diagnozą. Stwierdzenie to jest również prawdziwe dla awialingwistyki, która pozyskuje wiedzę o danym języku lotniczym od osób posługujących się nim w codziennych sytuacjach zawodowych. Diagnoza, czyli inaczej zbieranie wiedzy na temat podzbiorów języka lotniczego, to zadanie należące do awialingwistyki czystej. Polega ona na obserwowaniu elementów, które konstytuują jej przedmiot, a następnie analizowaniu tekstów wykorzystujących takie elementy. W ten sposób otrzymujemy aktualny obraz danego podzbioru języka lotniczego.

Według S. Gruczy (2013) wiedzę pozyskaną w ramach anagnozy traktować można jako pewnego rodzaju uwierzytelnienie zarówno wiedzy diagnostycznej, jak i jej celów. Mamy tu zatem do czynienia z bieżącym zastosowaniem języka lotniczego we wszystkich jego aspektach i tylko w ten sposób możemy określić, czy spełnia on przypisane mu funkcje.

\footnotetext{
${ }^{5}$ ang. aviation language - język lotniczy
} 
Zadania prognostyczne mają na celu kontynuację zadań diagnostycznych z uwzględnieniem badań przeprowadzonych na skutek anagnozy. Dlatego też na podstawie powyższych założeń możemy stwierdzić, że to właśnie awialingwistyka stosowana obejmuje zadania prognostyczne. Należy do nich przede wszystkim nakreślenie potrzeb praktycznych i ewentualne usprawnienie samych języków lotniczych, a także kompetencji językowych ich użytkowników. Zadania prognostyczne mają zatem zapobiegać wszelkim zakłóceniom, które mogłyby pojawić się w dyskursie lotniczym.

Ze względu na swoje ściśle określone funkcje, dyskurs lotniczy powinien być nieustannie monitorowany $\mathrm{w}$ odniesieniu do operacji lotniczych przeprowadzanych w warunkach wysokiego ryzyka. Bezpieczeństwo każdego lotu to wynik skutecznej komunikacji nie tylko pomiędzy pilotem i kontrolerem ruchu lotniczego, ale przede wszystkim wszystkich osób zawodowo zaangażowanych $\mathrm{w}$ jego przygotowanie, począwszy od projektantów statku powietrznego, ustawodawców, mechaników lotniczych, poprzez personel naziemny, personel pokładowy, członków załogi lotniczej, kontrolerów ruchu lotniczego, a skończywszy na służbach lotniskowych i ratowniczych. Wszyscy przedstawiciele zawodów związanych z lotnictwem powinni się poprawnie ze sobą komunikować. Zakres wiedzy specjalistycznej wykorzystywany w komunikacji lotniczej jest zatem olbrzymi. Do ogólnych zadań badawczych awialingwistyki można zatem zaliczyć: nakreślenie ram teoretycznych języka lotniczego i jego podzbiorów, analizę dyskursu lotniczego, analizę tekstu lotniczego, ale także opis szkoleń podnoszących kompetencje językowe dla kadr przemysłu lotniczego i dziedzin z nim powiązanych, udoskonalenie specjalistycznych szkoleń dla trenerów języka lotniczego, tworzenie prac leksykograficznych, szkolenie tłumaczy i wsparcie pracy terminologicznej.

Nie sposób wymienić tu wszystkich zadań badawczych, jakie stoją przed awialingwistyką. Zawężam je zatem do wybranego przykładu - dyskursu aeronautycznego, który ilustruje wyraźnie bieżące potrzeby lotnictwa w wybranym aspekcie i następnie pozwala na wyszczególnienie zadań badawczych w nieco węższym kontekście. W celu bezpiecznego wykorzystania przestrzeni powietrznej i powierzchni lotniskowej niezbędna jest poprawna komunikacja powietrze-ziemia, a w niektórych przypadkach powietrze-powietrze. Przedstawiony w punkcie 2 powyżej dyskurs aeronautyczny ma na celu gwarancję bezpieczeństwa w każdej fazie lotu:

Nieprawidłowo przebiegająca komunikacja pilot-wieża może doprowadzić do wtargnięcia statku powietrznego na pas startowy, wypadnięcia z trasy, zderzenia statków powietrznych. Okazuje się, że w większości przypadków zakłócenia komunikacji pilotwieża są skutkiem słabej znajomości języka obowiązującego zarówno w przestrzeni powietrznej, jak również w międzynarodowych portach lotniczych, tj. angielskiego języka lotniczego" ${ }^{6}$ (A.P. Borowska 2012: 19).

${ }^{6}$ Tradycyjnie zwanego Aviation English, ale w celu doprecyzowania pełnionych przez niego funkcji stosuje się także termin Aeronautical English (np. A.P. Borowska 2017a, P. Ragan 1993, F. Rubenbauer 2009), który zawęża obszar jego wykorzystywania.

Lingwistyka Stosowana/ Applied Linguistics/ Angewandte Linguistik: www.ls.uw.edu.pl 
Jednak po wielu analizach dialogów aeronautycznych pomiędzy rodowitymi mówcami języka angielskiego, a mówcami, dla których język angielski jest językiem obcym, wspomniana słaba znajomość języka obecnie nabiera szerszego wymiaru. Badania (A.P. Borowska 2016, 2017a) wykazały, że przeszkodą w komunikacji interkulturowej jest coraz częściej także niechęć do stosowania frazeologii standardowej przez rodowitych mówców języka angielskiego lub brak umiejętności upraszczania stosowanych przez nich struktur gramatycznych i leksykalnych ogólnego języka angielskiego, szczególnie podczas komunikacji z mówcami, dla których język angielski jest językiem obcym i którzy na obowiązkowym egzaminie językowym uzyskali najniższy poziom językowy, tzw. poziom operacyjny ICAO 4 . W rezultacie, należy grupę rodowitych mówców języka angielskiego włączyć do badań nad dyskursem aeronautycznym. Ponadto coraz częściej uwaga badaczy języka lotniczego skierowana jest także na aspekty pozajęzykowe werbalnej komunikacji lotniczej (np. M. Bieswanger 2013, A.P. Borowska 2013, 2017a, 2017b, 2017c, A. Hazrati 2015, ICAO Doc. 9835 2010). Należą do nich między innymi: świadomość interkulturowa, kultura dominująca, kompetencje interkulturowe oraz świadome stosowanie strategii komunikacyjnych. Poniższy przykład (4) dialogu ilustruje językowe, ale także pozajęzykowe problemy komunikacji pilot-kontroler, w której warto zwrócić uwagę, w jaki sposób buduje swoje wypowiedzi kontroler, który jest Amerykaninem:

Przykład (4)

Pilot: Ground, TURKISH11 Heavy.

Kontroler: TURKISH11, Kennedy.

Pilot: Now we're approaching V and new gate will be 6 at terminal 1, TURKISH11. Kontroler: OK, I understand you're going to gate 6. There's an airplane on it. Hold short of $\mathrm{V}$.

Pilot: Hold short of V, TURKISH11.

Kontroler: Tell your ramp not tell you to tell me anything until they have a gate you can actually get to.

Pilot: Ground, TURKISH11 Heavy, our gate 6 at terminal 1 is open.

Kontroler: OK, very good, he can...Unfortunately with that gate, until he comes out, you can't get in. So, just hold there. Looks like he's little bit closer of actually coming out.

Pilot: OK, TURKISH11.

(www.liveATC.net, JFK)

Chociaż kontroler zauważa, że pilot nie posługuje się na tyle płynnie językiem angielskim, żeby brać udział w szybkiej wymianie zdań, nie rezygnuje ze swoich komentarzy. Co więcej, kontroler wypowiada je szybko, nie zważając ani na czasow-

\footnotetext{
${ }^{7}$ ICAO Language Proficiency Rating Scale w: ICAO Doc. 9835. Manual on the Implementation of ICAO Language Proficiency Requirements, 2nd edition, (2010), Montreal: ICAO.
} 
niki złożone, ani na fakt, że zamiast krótkich i jasnych poleceń konstruuje zawiłe komentarze, które mogą wprowadzić pilota w błąd. Ponadto kontroler wyraźnie preferuje język potoczny od standardowej frazeologii. Można też stwierdzić, że poprzez tego typu zabiegi językowe kontroler zaznacza także swoją kulturowość.

Ze względu na fakt, że różnorodność błędów popełnianych przez użytkowników angielskiego języka aeronautycznego wzrasta, tym samym zagrażając bezpieczeństwu lotu, powinny one być nieustannie badane względem mających miejsce incydentów lotniczych, w których za główną przyczynę nieporozumień uznano język. Tylko dążenie do unikania podobnych błędów, ale także promocja poprawnych zachowań werbalnych (A.P. Borowska 2017d) może znacząco przyczynić się do bezpieczeństwa lotów $\mathrm{w}$ przyszłości.

W samym kontekście aeronautycznym zadania badawcze awialingwistyki bardzo się różnicują od teoretycznych do aplikatywnych, a bieżące potrzeby, zgodnie z wynikami przeprowadzonych badań, wskazują przede wszystkim na usprawnienie komunikacji w angielskim języku aeronautycznym. Oznacza to ulepszenie nie tylko stwierdzonego stanu tekstów aeronautycznych, czyli sposobów ich tworzenia i możliwości rozumienia, ale przede wszystkim samego języka aeronautycznego, co na poziomie teoretycznym oznacza ulepszenie jego obecnego stanu, a na poziomie aplikatywnym - ulepszenie dotychczasowego posługiwania się nim. Aby tego dokonać, należy w pierwszej kolejności uwzględnić następujące zadania cząstkowe:

- obserwacja angielskiego dyskursu aeronautycznego i jego segmentów na wszystkich możliwych poziomach (np. syntaktycznym, fonologicznym, leksykalnym);

- analiza angielskiego dyskursu aeronautycznego i jego segmentów;

- analiza interkulturowej świadomości językowej uczestników dyskursu aeronautycznego;

- $\quad$ szczegółowy opis stosowanego angielskiego języka aeronautycznego obejmującego standardową frazeologię i ogólny angielski język aeronautyczny;

- analiza i opis błędów językowych i pozajęzykowych popełnianych przez uczestników dyskursu aeronautycznego (w tym rodowitych mówców języka angielskiego);

- zbadanie skutecznych i nieskutecznych strategii komunikacyjnych stosowanych w dyskursie aeronautycznym;

- analiza stosowanych metod nauczania języka aeronautycznego na tle problemów napotykanych podczas komunikacji aeronautycznej, w tym dobór odpowiednich technologii w procesie nauczania, przygotowywanie materiałów dydaktycznych;

- analiza metod testowania i oceniania języka aeronautycznego z uwzględnieniem częstych incydentów lotniczych;

- opracowanie testów językowych;

- opracowanie programu szkoleń dla wszystkich uczestników dyskursu aeronautycznego. 
Powyższa lista zadań badawczych nie jest listą zamkniętą. W zależności od zaistniałych potrzeb można ją poszerzać, a nawet po wykonaniu niektórych z nich - zawężać. Jednak pełne wykonanie zadania głównego ma pewne ograniczenia, ponieważ W rzeczywistości globalnej wiąże się ono z wprowadzeniem opracowanych zaleceń w życie. W przypadku lotnictwa jest to możliwe tylko przy współpracy z organizacjami lotniczymi za pomocą właściwych przepisów międzynarodowych.

\section{Wnioski}

Zarysowanie zadań badawczych awialingwistyki pozwoliło uściślić pytania dotyczące zakresu, jakim ta dyscyplina wiedzy się zajmuje. Uwzględniając powyższe założenia, można z łatwością stwierdzić, że zadania badawcze awialingwistyki są bardzo zrożnicowane i można je szczegółowo i pełnie przedstawić tylko po określeniu konkretnego przedmiotu badawczego, zawsze biorąc pod uwagę bieżące potrzeby lotnictwa. Kolejnym krokiem powinno być określenie, czy dane zadanie badawcze wpisuje się w awialingwistykę czystą czy stosowaną, czy może w oba jej rodzaje. Ważnym aspektem przy precyzowaniu problemów badawczych jest także uwzględnienie triady zadań: diagnozy, anagnozy i prognozy, a następnie, na podstawie przedstawionych w ogólnym zakresie założeń, przy wykorzystaniu wiedzy specjalistów dwóch dziedzin lotnictwa i lingwistyki, sprecyzowanie zadań cząstkowych. Przedstawione w artykule zagadnienia mają na celu kontynuację dyskusji na temat kształtu awialingwistyki i przedmiotu jej badań.

\section{Bibliografia}

Bieswanger, M. (2013), Applied Linguistics and Air Traffic Control: Focus on Language Awareness and Intercultural Communication, (w:) S. Hansen-Schirra/ K. Maksymski (red.), Aviation Communication: Between Theory and Practice. Frankfurt am Main, 15-31.

Bieswanger, M. (2016), Aviation English: Two distinct specialised registers?, (w:) C. Schubert/ C. Sanchez-Stockhammer (red.), Variational Text Linguistics Revisiting Register in English. Berlin, 67-86.

Borowska, A.P. (2012), Usprawnienie komunikacji pilot-wieża: zadanie dla lingwistyki języków specjalistycznych, (w:) S. Grucza (red.), „Lingwistyka Stosowana/ Applied Linguistics/ Angewandte Linguistik" 5/2012, 19-29.

Borowska, A. (2013), Shaping Cross-cultural Awareness in Aviation English Communication, referat wygłoszony na konferencji ICAEA pt.: „Cross-cultural Awareness in Aviation English Training”, Paryż, 18-19 kwietnia 2013.

(URL http://www.icaea.pata.pl/pliki/2013_Paris/prezentacje/11._Day_2_Anna_ Borowska. doc;

http://www.icaea.pata.pl/?opis=paris_2013_report.htm) [Pobrano 12.05.2014]

Borowska, A. (2016), Do Expert Speakers Need to Practice a Language?, (w:) A. Borowska/ A. Enright (red.), Changing Perspectives on Aviation English Training. Warszawa, 61-72. 
Borowska, A.P. (2017a), Avialinguistics. The Study of Language for Aviation Purposes. Frankfurt am Main.

Borowska, A.P. (2017b), Aviation Communication over the Borders of Ethnicity, referat wygłoszony na konferencji pt.: „Language and the space of ethnocultural dialogue" w ramach projektu badawczego Historia nationem gignit, SaintPetersburg State University, 22-24 marca 2017.

Borowska, A.P. (2017c), Is there any dominant culture in global aeronautical settings?, (w:) Strategies of Intercultural Communications in Teaching Languages at Modern University Annual International Scientific Conference of Kyiv National Economic University named after Vadym Hetman, (w druku).

Borowska, A.P. (2017d), Aeronautical English: an Analysis of Selected Communication Strategies used by Native English Speakers in Interaction with Operational Level 4 Personnel, (w:) "Proceedings of National Aviation University” 6/2017, 139-146.

Caldwell, J.A./ J.Y. Caldwell (2016), Fatigue in Aviation: A Guide to Staying Awake at the Stick, 2nd Edition. London/ New York.

Cookson, S. (2009), Zagreb and Tenerife: Airline accidents involving linguistic factors, (w:) „Australian Review of Applied Linguistics” 32 (3), 22.1-22.14.

Griffin, T.G.C./ M.S. Young/ N.A. Stanton (2015), Human Factors Models for Aviation Accident Analysis and Prevention. London/ New York.

Grucza, F. (2003), Zum Basisgenestand der polnischen (Universitäts)Germanistik: Versuch einer wissenschaftlichen Begründung ihrer Einheit, (w:) „Kwartalnik Neofilologiczny" L, 1-2, 99-115.

Grucza, F. (2007), Lingwistyka stosowana. Historia - zadania - osiagnięcia. Warszawa.

Grucza, S. (2004), Od lingwistyki tekstu do lingwistyki tekstu specjalistycznego.

Warszawa.

Grucza, S. (2008, 2013), Lingwistyka języków specjalistycznych. Warszawa.

Gunnarson, B.L. (2009), Professional Discourse. London/ New York.

Hazrati, A. (2015), Intercultural communication and discourse analysis: The case of Aviation English, (w:) „Procedia - Social and Behavioral Sciences” 192, 244251.

Hopkin, V.D. (1995), Human Factors In Air Traffic Control. London/ Bristol, PA.

ICAO (2010), Doc. 9835. Manual on the Implementation of ICAO Language Proficiency Requirements, 2nd edition, Montreal: ICAO.

Karpiński, J. (2015), Aviation Dutch? Próba definicji, (w:) „Lingwistyka Stosowana/ Applied Linguistics/ Angewandte Linguistik" 15: 4/2015, 21-31.

Listen to Live ATC (Air Traffic Control) Communications (URL www.liveatc.net) [Pobrano 23.11.2016]

Martinussen, M./ D.R. Hunter (2010), Aviation Psychology and Human Factors. Boca Raton.

Molesworth, B./ D. Estival, D. (2015), Miscommunication in general aviation: The influence of external factors on communication errors, (w:) „Safety Science” 73, 73-79. 
Muir, H.C./ D. Harris, (red.) (2005), Contemporary Issues in Human Factors and Aviation Safety. London/ New York.

Nowak, L. (1977), Wstęp do idealizacyjnej teorii nauki. Warszawa.

Ragan, P. (1993), Aeronautical English: Research and applications, referat wygłoszony na konferencji pt.: „27th International TESOL Conference”, Atlanta, GA.

Rubenbauer, F. (2009), Linguistics and Flight Safety: Aspects of Oral English Communication in Aviation. Aachen.

Tsang, P.S./ M.A. Vidulich (2002), Principles and Practice of Aviation Psychology. Boca Rotan.

Wise, J.A./ V.D. Hopkin/ D.J. Garland (2009), Handbook of Aviation Human Factors, Second Edition. London/ New York. 